\title{
Principles and Operational Parameters to Optimize Poison Removal with Extracorporeal Treatments
}

\author{
Josée Bouchard, * Darren M. Roberts, †‡ Louise Roy,§ Georges Ouellet, П \\ Brian S. Decker, ${ }^{* *}$ Bruce A. Mueller, $† \dagger$ Simon Desmeules, $\neq \ddagger$ and Marc Ghannoum§§ \\ *Division of Nephrology, Hôpital du Sacré-Coeur de Montréal, University of Montreal, Montreal, Quebec, \\ Canada, †Burns, Trauma and Critical Care Research Centre, School of Medicine, University of Queensland, \\ Brisbane, Queensland, Australia, fDepartment of Renal Medicine, Addenbrooke's Hospital, Cambridge, \\ United Kingdom, §Division of Nephrology, Centre Hospitalier Universitaire de Montréal, University of \\ Montreal, Montreal, Quebec, Canada, IDivision of Nephrology, Hôpital Maisonneuve-Rosemont, University \\ of Montreal, Montreal, Quebec, Canada, **Division of Nephrology, Indiana Institute for Personalized \\ Medicine, Indiana University School of Medicine, Indianapolis, Indiana, ††Department of Clinical Social and \\ Administrative Sciences, College of Pharmacy, University of Michigan, Ann Arbor, Michigan, fキDivision of \\ Nephrology, CHUQ-L'Hôtel Dieu de Québec Hospital, Laval University, Québec City, Quebec, Canada, \\ and $\S \S$ Department of Nephrology, Verdun Hospital, University of Montreal, Montreal, Quebec, Canada
}

\begin{abstract}
A role for nephrologists in the management of a poisoned patient involves evaluating the indications for, and methods of, enhancing the elimination of a poison. Nephrologists are familiar with the various extracorporeal treatments (ECTRs) used in the management of impaired kidney function, and their respective advantages and disadvantages. However, these same skills and knowledge may not always be considered, or applicable, when prescribing ECTR for the treatment of a poisoned patient.
\end{abstract}

Maximizing solute elimination is a key aim of such treatments, perhaps more so than in the treatment of uremia, because ECTR has the potential to reverse clinical toxicity and shorten the duration of poisoning. This manuscript reviews the various principles that govern poison elimination by ECTR (diffusion, convection, adsorption, and centrifugation) and how components of the ECTR can be adjusted to maximize clearance. Data supporting these recommendations will be presented, whenever available.

\section{Principles of Poison Removal}

The various methods available for poison removal by ECTR are diffusion, convection, adsorption, and centrifugation. This manuscript reviews the principles and parameters that may influence poison clearance. A detailed understanding of these principles is useful for the nephrologist because they guide how adjustments to the ECTR prescription can optimize solute clearance. These principles can be used to individualize ECTR in the context of its indication.

\section{Diffusion}

Thomas Graham first suggested the concept of dialysis in 1861, based on the process of diffusion.

Address correspondence to: Dr. Marc Ghannoum, Verdun Hospital, 4000 Lasalle Blvd, Montreal, QC, Canada, Tel.: 514 362-1000, Fax: 514 504-1245, or

e-mail: marcghannoum@gmail.com.

Seminars in Dialysis-Vol 27, No 4 (July-August) 2014 pp.

371-380

DOI: $10.1111 /$ sdi. 12247

(C) 2014 Wiley Periodicals, Inc.
During diffusion, the movement of particles (solutes) is driven by a concentration gradient from one compartment to another through a semi-permeable membrane. In the case of hemodialysis, the two compartments are the blood and dialysate and mainly small molecules (defined as a molecular weight (MW) less than 500-1000 Da), and some middle molecules, readily cross the filter membrane.

Operational characteristics influencing diffusive clearance include the magnitude of the concentration gradient (blood and dialysate flow rates), duration of therapy, and the filter composition. These factors will be discussed here and are also summarized in Table 1.

\section{Maximization of Blood and Countercurrent Dialysate Flow Rates}

Principles. Both blood $\left(Q_{\mathrm{B}}\right)$ and dialysate $\left(Q_{\mathrm{D}}\right)$ flows influence solute clearance. In general, the maximum possible clearance corresponds to the slower of the two flows, which will be the rate-limiting step. In intermittent hemodialysis (IHD), $Q_{\mathrm{B}}$ is usually slower than $Q_{\mathrm{D}}$, whereas the opposite is true in continuous venovenous hemodialysis (CVVHD). 
TABLE 1. Summary of the most important parameters for optimizing clearance with the different extracorporeal therapies

\begin{tabular}{|c|c|c|c|}
\hline & \multicolumn{3}{|c|}{ Operational parameters to optimize clearance } \\
\hline & $\begin{array}{l}\text { For small molecules } \\
(\mathrm{MW}<500-1000 \mathrm{Da})\end{array}$ & For middle-sized molecules & $\begin{array}{l}\text { For protein-bound } \\
\text { molecules }(>80 \%)\end{array}$ \\
\hline Diffusion (e.g. IHD) & $\begin{array}{l}\text { High } Q_{\mathrm{B}} \text { (up to } 400 \mathrm{ml} / \text { minute) }{ }^{\text {a }} \\
\text { Ratio } Q_{\mathrm{D}}: Q_{\mathrm{B}} \geq 2.5 \\
\text { High-efficiency filter } \\
\text { Adding a second filter? }\end{array}$ & $\begin{array}{l}\text { Convection preferred over diffusion } \\
\text { High-flux filter } \\
\text { surface } \text { area }^{\mathrm{a}} \\
\text { High } Q_{\mathrm{B}} \\
\text { Adding a large } \\
\text { Adecond filter? }\end{array}$ & $\begin{array}{l}\text { High } Q_{\mathrm{D}} \\
\text { Filter with a large } \\
\text { surface area } \\
\text { Adding a second filter? }\end{array}$ \\
\hline $\begin{array}{l}\text { Convection } \\
\text { (Intermittent hemofiltration) }\end{array}$ & $\begin{array}{l}\text { High } Q_{\mathrm{B}}{ }^{\mathrm{a}} \\
\text { High } Q_{\mathrm{UF}}^{\mathrm{a}} \\
\text { Maximize postdilution then } \\
\text { add predilution }\end{array}$ & $\begin{array}{l}\text { High } Q_{\mathrm{B}} \\
\text { High } Q_{\mathrm{UF}}{ }^{\text {a }}, \text { maximize postdilution } \\
\text { then add predilution } \\
\text { High-flux filter }\end{array}$ & $\begin{array}{l}\text { High-flux filter } \\
\text { Predilution? }\end{array}$ \\
\hline $\begin{array}{l}\text { Convection \&/or diffusion } \\
\text { (in CRRT) }\end{array}$ & $\begin{array}{l}\text { High } Q_{\text {effluent }}\left(Q_{\mathrm{D}}>Q_{\mathrm{UF}}\right)^{\text {a }} \\
\text { High } Q_{\mathrm{B}} \\
\text { Maximize postdilution then } \\
\text { add predilution } \\
\text { High-efficiency filter } \\
\text { Filter changed }<48 \text { hours } \\
\text { Adding a second filter? }\end{array}$ & $\begin{array}{l}\text { High } Q_{\text {effluent }}\left(Q_{\mathrm{UF}}>Q_{\mathrm{D}}\right)^{\mathrm{a}} \\
\text { Maximize convection: CVVH }> \\
\text { CVVHDF (because replacement } \\
\text { fluid is greater) } \\
\text { High } Q_{\mathrm{B}} \\
\text { High-flux filter } \\
\text { Filter changed }<48 \text { hours } \\
\text { Adding a second filter? }\end{array}$ & \\
\hline Adsorption (e.g. IHP) & \multicolumn{3}{|c|}{$\begin{array}{l}\text { Charcoal vs. resin column (depending on poison)* } \\
\text { High } Q_{\mathrm{B}}(\max 350 \mathrm{~mL} / \mathrm{min}) \\
\text { Filter change }<4 \text { hours }\end{array}$} \\
\hline $\begin{array}{l}\text { Centrifugation } \\
\text { (e.g. therapeutic plasma } \\
\text { exchange) }\end{array}$ & \multicolumn{3}{|c|}{$\begin{array}{l}\text { Centrifugation or filtration } \\
\geq 2 \text { plasma volumes exchanged* } \\
\text { Central catheter } \\
\text { High } Q_{\mathrm{B}}(100-200 \mathrm{ml} / \mathrm{min} \text { for filtration and } 100 \mathrm{ml} / \mathrm{min} \text { for centrifugation) } \\
\text { Replacement fluid tailored to the poison } \\
\text { Heparin vs. citrate anticoagulation }\end{array}$} \\
\hline For all processes & \multicolumn{3}{|c|}{$\begin{array}{l}\text { Right jugular catheter } \geq \text { femoral. For a femoral site, use catheter }>20 \mathrm{~cm} \text { long. Subclavian site } \\
\text { probably equivalent to jugular but avoid in patients at risk for end-stage renal disease. } \\
\text { Both subclavian and jugular sites may require X-ray confirmation of placement. } \\
\text { Longer treatment time }\end{array}$} \\
\hline
\end{tabular}

CRRT, continuous renal replacement therapy; CVVH, continuous venovenous hemofiltration; CVVHDF, continuous venovenous hemodiafiltration; MARS, molecular adsorbent recirculating system; SPAD, single pass albumin dialysis; $\mathrm{Q}_{\mathrm{B}}$, blood flow rate; $\mathrm{Q}_{\mathrm{D}}$, dialysate flow rate; QuF, ultrafiltration rate.

${ }^{\mathrm{a}}$ Most important.

Therefore, when adjusting the dialysis prescription to maximize solute clearance, the greatest impact will follow an increase in $Q_{\mathrm{B}}$ in IHD, compared with an increase in $Q_{\mathrm{D}}$ in CVVHD.

Because the mobility of the solute between the compartments influences clearance, the clearance of small water-soluble solutes will exceed that of larger particles.

Peritoneal dialysis (PD) has been used for the treatment of acute poisoning and clearance is also influenced by $Q_{\mathrm{D}}$. However, PD is not usually recommended in the treatment of poisoning because clearance is universally less than that achieved with other ECTRs.

Supporting Data. In IHD, an increase of 100 $200 \mathrm{ml} /$ minute in $Q_{\mathrm{B}}$ will significantly enhance the clearance of small solutes like urea (1-8). A similar effect is, therefore, expected for small poisons like lithium and alcohols.

In IHD, some authors suggest targeting a $Q_{\mathrm{D}} / Q_{\mathrm{B}}$ ratio $>2.5: 1$ to ensure that clearance of small molecules is not restricted by dialysate flow (9). Therefore, if a $Q_{\text {B }}$ of $400 \mathrm{ml} /$ minute is achievable, $Q_{\mathrm{D}}$ should opti- mally be $1000 \mathrm{ml} /$ minute, although any increment over $600 \mathrm{ml} /$ minute only modestly improves performance (10). A mechanism by which $Q_{\mathrm{D}}$ increases clearance is via better distribution of flow between the filter bundles, thereby increasing the effective surface of the filter. In addition, countercurrent direction of dialysate flow provides $20-30 \%$ better clearances for small molecules than a concurrent direction of flow (11).

In CVVHD, an increase in $Q_{\mathrm{D}}$ will improve small solute clearance with a near-linear relationship (Fig. 1) (12-17).

Although there are some limitations, these principles also apply to protein-bound toxins and medicines such as phenol, p-cresol, hippurate, carbamazepine, and valproic acid $(15,18-20)$, particularly when protein binding is saturated (21).

There are data supporting the application of these principles in the treatment of poisoned patients. For example, increasing $Q_{\mathrm{B}}$ from 200 to $300 \mathrm{ml} /$ minute in IHD increases the clearance of valproic acid from 43 to $80 \mathrm{ml} /$ minute (22). Increasing $Q_{\mathrm{B}}$ also increases the clearance of middle molecules like vancomycin when a high-flux filter is used (23). Similar results were shown in poisonings to phenobarbi- 


\section{$Q_{d}$ vs CL}

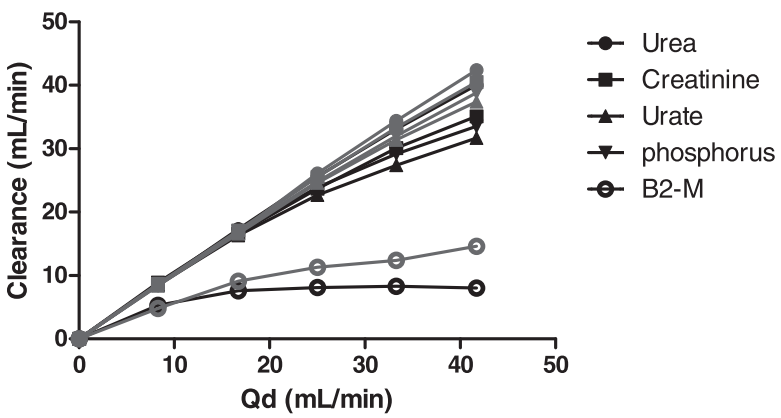

FIG. 1. Influence of $Q_{\mathrm{D}}$ and molecular weight on mean solute clearance at $Q_{\mathrm{B}} 150 \mathrm{ml} /$ minute. Color indicates the type of filter, where black-colored has a surface area of $0.6 \mathrm{~m}^{2}$ and gray-colored has a surface area of $0.9 \mathrm{~m}^{2}$ (graphs redrawn from data in Brunet et al (13)., with permission from Elsevier)

tal, lithium, and phenytoin, where clearance plateaued when $Q_{\mathrm{B}}$ exceeded approximately $300 \mathrm{ml} / \mathrm{min}$ ute in the context of $Q_{\mathrm{D}} 500 \mathrm{ml} /$ minute $(24,25)$.

Peritoneal dialysis (PD) also uses the principle of passive diffusion, although fluid and solute exchange occurs in the peritoneal cavity across the peritoneal membrane. The use of PD in poisoning has almost disappeared due to its limited clearance capacity compared with IHD (26-29). In PD, increasing the dialysate flow rate $\left(Q_{\mathrm{D}}\right)$ maximizes clearance. Increasing $Q_{\mathrm{D}}$ is possible by increasing the frequency and volume of the exchanges $(28,30-$ 32). Extremely high dialysate flows, provided by continuous-flow PD over a short period of time, may allow good clearance of solutes that readily diffuse through the peritoneal membrane. For example, a urea clearance of $35 \mathrm{ml} /$ minute was achieved when dialysate flow was 6-91/hour $(33,34)$, and $48 \mathrm{ml} /$ minute when using a double-lumen catheter (35). In another study, methanol clearance was $70 \mathrm{ml} /$ minute with a dialysate flow of $61 /$ hour (36), a significant result but still minor compared with that obtained by IHD (37). Small MW clearance may be enhanced when PD is performed in the supine position (38). Tidal PD does not appear to improve clearance over intermittent PD (39).

Limitations. Increases in $Q_{\mathrm{B}}$ and $Q_{\mathrm{D}}$ are associated with a lesser increase in clearance of middlesized molecules by diffusion, such as vitamin $\mathrm{B}_{12}$ (40) (MW $1355 \mathrm{Da}$ ) and $\beta_{2}$-microglobulin $(1,9,10)$ (MW 11,000 Da) (Fig. 1), and no significant change for larger molecules like dextran (41).

$Q_{\mathrm{B}}$ is usually limited to $<400 \mathrm{ml} /$ minute when using an intravascular catheter due to blood turbulence and resistance in the tubing. However, advances in catheter design may allow for greater $Q_{\text {B }}$ (42-44). Notably, however, increasing levels of blood recirculation (compromising clearance) occur when $Q_{\mathrm{B}}$ exceeds $400 \mathrm{ml} /$ minute in femoral vein catheters.

In IHD, increasing the $Q_{\mathrm{D}}: Q_{\mathrm{B}}$ ratio does not proportionally increase solute clearance. For example, for a $Q_{\mathrm{B}}$ of $300 \mathrm{ml} /$ minute, augmenting $Q_{\mathrm{D}}$ from
300 to $500 \mathrm{ml} /$ minute will increase clearance by a greater proportion than an increase from 500 to $800 \mathrm{ml} /$ minute, regardless of the filter used $(1,2,4,9,45)$. Augmenting $Q_{\mathrm{D}}$ increases clearance by approximately $10-20 \%$ for small MW molecules (1$3,10,13,20,46)$, but does not affect the clearance of larger molecules $(13,14,47)$. A dialysate flow over $800 \mathrm{ml} /$ minute may exceed the operational capacity of some machines and/or increase the cost of the treatment due to the larger volume of dialysate solutions.

In CVVHD, because $Q_{\mathrm{B}}$ is already approximately three times higher than $Q_{\mathrm{D}}$, there is no benefit from further increases in $Q_{\mathrm{B}}$, at least with a $Q_{\mathrm{D}}$ up to 4 1/hour $(12,15)$.

\section{Use of a High-Efficiency Filter, Particularly for Smaller Solutes}

Principles. Efficiency and flux are two characteristics of filters that relate to solute clearance, reflecting filter surface area and composition.

Efficiency refers to the capacity to clear urea, which is a surrogate measure of low MW solutes, and is quantified by the product of its mass transfer area coefficient $(K o)$ and surface area $(A), K o A$. The higher the $K o A$ of a filter, the higher will be the clearance of small solutes. The actual clearance achieved by a particular filter depends on the MW of the solute and other specifics of the dialysis prescription, in particular the $Q_{\mathrm{B}}$ and $Q_{\mathrm{D}}$, as well as ultrafiltration. Therefore, some aspects relating to convection are also discussed here.

In contrast, flux refers to the permeability of the filter to middle-sized MW solutes; it is most often assessed using $\beta_{2}$-microglobulin (MW 11,000 daltons). The ultrafiltration capacity of the filter, quantified according to the ultrafiltration coefficient $\left(K_{\mathrm{UF}}\right)$, typically correlates with this $(48)$.

The simultaneous use of two filters or machines will further increase clearance.

Supporting Data. Extracorporeal membranes can be characterized by their surface area, material, morphology, fiber length and thickness, permeability to water, and hydrophilicity (Table 2). Newer synthetic filters differ dramatically from conventional filters used prior to the 1990s in their clearance capacity and biocompatibility (49).

The $K o A$ estimates the maximum clearance of urea by the filter when $Q_{\mathrm{B}}$ and $Q_{\mathrm{D}}$ are infinite $(1,2,6)$. High-efficiency membranes are defined as having a $K_{O} A>600 \mathrm{ml} /$ minute (50) and much of the gain in $K o A$ relates to an increase in surface area. The clearance of middle molecules such as $\mathrm{B}_{12}(40)$, teicoplanin (47), and $\beta_{2}$-microglobulin (1) can also slightly increase with the use of a large surface area filter. Clearance of protein-bound solutes can also increase (18-20), although not consistently (51).

With high-flux membranes, there is improved clearance of larger MW solutes relative to small MW solutes $(41,49)$. This concept reflects the greater solute permeability of high-flux membranes. 
TABLE 2. Dialyzer classification

\begin{tabular}{|c|c|c|c|c|c|}
\hline & Surface area $\left(\mathrm{m}^{2}\right)$ & $K_{\mathrm{UF}}(\mathrm{ml} / \mathrm{h} / \mathrm{mmHg})$ & $B_{2}$-microglobulin clearance ( $\mathrm{ml} /$ minute) & Albumin loss & Application \\
\hline Conventional & $<1.5 \mathrm{~m}^{2}$ & $0-10$ & $<20$ & 0 & HD \\
\hline High-flux & Variable & $20-40$ & $>40$ & + & $\mathrm{HD}, \mathrm{HF}, \mathrm{HDF}$ \\
\hline High-efficiency & $>1.5 \mathrm{~m}^{2}$ & $0-10$ & $<20$ & + & HD \\
\hline Protein leaking & & $>40$ & $>80$ & +++ & HD \\
\hline
\end{tabular}

HD, hemodialysis; HF, hemofiltration; HDF, hemodiafiltration.

The simultaneous use of more than one filter, or even two distinct circuits, can increase clearance. Using two filters in parallel circuits has the effect of increasing the surface area for filtration and improves clearance of small molecules; it may be of particular benefit in larger sized patients (52). This set-up can also increase the clearance of other small and middle MW compounds (40), like iohexol (52). In contrast, adding a second filter in series may improve the overall clearance of small $(19,53)$, middle molecules (40), and also protein-bound solutes (19). This has also been applied to poisoning cases, when two circuits were used to facilitate elimination enhancement of metformin $(54,55)$.

Limitations. Clearance of middle MW solutes varies among types/brands of high-flux filters, which limits generalizability. For example, the clearance of $\beta_{2}$-microglobulin clearance differed almost two-fold between filters with similar surface area (56), which may be due to other processes such as molecule trapping and adsorption.

There are limited data about the cost-benefit ratio of simultaneously using two filters/machines in poisoned patients. Although either is anticipated to increase clearance, more research is required to confirm its effect and role in clinical management. Current evidence suggests that the benefit of either configuration (series or parallel) provides an incremental clearance gain of approximately 5-7\% $(52,53)$; however, a potential downside in the use of two filters is cost and that it may delay the start of the procedure.

High-flux filters are capable of removing molecules as large as myoglobin (MW 17,200 Da) by diffusion, although significantly less than by convection for this range of MW (57).

\section{Addition of Albumin to Dialysate}

The underlying principle of albumin dialysis is that addition of albumin to the dialysate may facilitate clearance of highly protein-bound toxins because the unbound fraction diffuses into the dialysate side where it binds to albumin and is trapped. This creates a protein-binding disequilibrium on the blood side and more drug would become unbound and cross the membrane to be cleared. These techniques have been used in the treatment of intoxications with varying degrees of success and supporting clinical data are scarce $(58,59)$.

$Q_{\mathrm{B}}$ and $Q_{\mathrm{D}}$ influence solute clearance in albumin dialysis (60). For example, in an in vitro model of
CVVHD with albumin-supplemented dialysate $(2.5 \% \mathrm{~g} / \mathrm{l})$, an increase in $Q_{\mathrm{D}}$ will greatly influence the clearance of bound solutes, while increments in $Q_{\text {B }}$ had an almost null effect (15). A favorable impact of larger albumin concentration on clearance of protein-bound toxins has been reported for diazepam (61), as well as for valproic acid and carbamazepine (15), but not for phenytoin (15). Also, higher surface area filters increase clearance by albumin dialysis compared with lower ones (15). Other factors impacting clearance of extracorporeal liver assist devices (ELADs) are pore size, placement of filters, membrane material, amount and active surface of adsorbers, as well as free fraction of albumin-bound substances and time on therapy (62).

\section{Convection}

During convection, the patient's blood passes through a circuit and makes contact with a semipermeable filter. A positive transmembrane pressure forces water to cross the filter and solutes follow the bulk movement of the solvent (water; known as solvent drag). Convection allows middle molecules to be cleared much more efficiently than with diffusion. The only ECTR that utilizes convection exclusively for clearance of uremic toxins is hemofiltration (HF). Large volumes of replacement fluid are required and can be infused before (predilution), after (postdilution), or before and after (mixed dilution) the hemofilter in continuous and intermittent $\mathrm{HF} / \mathrm{HDF}$. The replacement fluid can also be infused with a special filter design called mid-dilution in intermittent hemofiltration. Operational characteristics influencing solute clearance during convection include $Q_{\mathrm{B}}$, ultrafiltration rate $\left(Q_{\mathrm{UF}}\right)$, the site of fluid replacement, and the type of hemofilter (Tables 1 and 3).

Although convection is often used in intermittent dialysis to remove excess fluid in ESRD, its impact on solute clearance is likely negligible because ultrafiltration during IHD rarely surpasses $25 \mathrm{ml} /$ minute.

\section{Maximization of the Blood and Ultrafiltration Rates}

Principles. Clearance increases when either $Q_{\mathrm{B}}$ and/or $Q_{\mathrm{UF}}$ are increased, analogous to the principles previously discussed for diffusion. In continuous venovenous $\mathrm{HF}(\mathrm{CVVH})$ and postdilution intermittent $\mathrm{HF}, Q_{\mathrm{B}}$ exceeds $Q_{\mathrm{UF}}$, so $Q_{\mathrm{UF}}$ is the rate-limiting step; $Q_{\mathrm{B}}$ may be the rate-limiting step 
TABLE 3. Relative comparison of the influence of the different parameters on the clearance of small and middle molecules in intermittent hemodiafiltration

\begin{tabular}{llll}
\hline & $\begin{array}{c}\text { Increasing } \\
\text { surface } \\
\text { area from } \\
1.4 \text { to } 2.2 \mathrm{~m}^{2}\end{array}$ & $\begin{array}{c}\text { Increasing } Q_{\mathrm{B}} \\
\text { from } 300 \text { to } \\
500 \mathrm{ml} / \mathrm{minute}\end{array}$ & $\begin{array}{c}\text { Addition } \\
\text { of convection }\end{array}$ \\
\hline Urea & $6 \%$ & $40 \%$ & $18 \%$ \\
$\beta_{2^{-}}$ & $22 \%$ & $16 \%$ & $75 \%$ \\
microglobulin & & & \\
\hline
\end{tabular}

Data adapted from Wizemann, 2001 (45).

in intermittent $\mathrm{HF}$ with the predilution mode, as $Q_{\mathrm{UF}}$ can be similar or exceed $Q_{\mathrm{B}}$.

Clearance by postdilution $\mathrm{HF}$ is superior to predilution HF when all other factors are equal. However, the maximum possible $Q_{\mathrm{UF}}$ with postdilution is less than that which can be achieved with predilution. To maximize clearance by convection, administration of the highest tolerable postdilution $\mathrm{HF}$ should be combined with some predilution.

Supporting Data. The effect of convection on the clearance of middle molecules is exemplified for $\beta_{2^{-}}$ microglobulin; its clearance by IHD when using a high-flux membrane is $20-40 \mathrm{ml} /$ minute under usual IHD operational conditions, but when the same membrane is used with HF, clearance is 100$150 \mathrm{ml} /$ minute $(45,63)$. This is further supported by studies with $B_{2}$-microglobulin and complement factor D $(24,000 \mathrm{Da})$, although the achieved clearance is highly dependent on $Q_{\mathrm{UF}}(45,64-71)$. The difference in clearances between convection and diffusion increases as the solute's MW increases. For example, vancomycin removal (MW $1448 \mathrm{Da}$ ) is about $20 \%$ greater during convection compared with diffusion. Daptomycin (MW $1620 \mathrm{Da}$ ) clearance is $>25 \%$ higher by HF than HD at standard CRRT effluent rates (72).

The clearance of small and middle molecules proportionately increases with higher $Q_{\mathrm{UF}}(13,14$, $65,66,71)$ whether using intermittent $\mathrm{HF}, \mathrm{CVVH}$ (Fig. 2), or continuous venovenous hemodiafiltration (CVVHDF)(73). In postdilution HF, the clearance of small molecules is approximately equal to $Q_{\text {UF. Increasing }} Q_{\text {UF }}$ to exceed 4-6 1/hour is associated with a smaller proportional increase in overall clearance. Increasing $Q_{\mathrm{B}}$ allows a higher postdilution $Q_{\mathrm{UF}}$ without compromising the filtration fraction (74). Once $Q_{\mathrm{UF}}$ exceeds 4-6 1/hour, $Q_{\mathrm{B}}$ should be maximized to 350 or even $450 \mathrm{ml} /$ minute if tolerated (75).

Although postdilution HF provides higher convective clearances than predilution at the same $Q_{\mathrm{UF}}$, greater replacement volumes can be administered in predilution $\mathrm{HF}$ so the maximum possible clearance could exceed that achieved by postdilution HF. With predilution HF alone, there is a decrease in the concentration of the solute, so each incremental increase in $Q_{\text {UF }}$ has a more modest impact on small nonprotein-bound molecule removal $(45,75)$, although the effect remains significant, even for $\beta_{2}$-microglobulin
QuF Vs CL

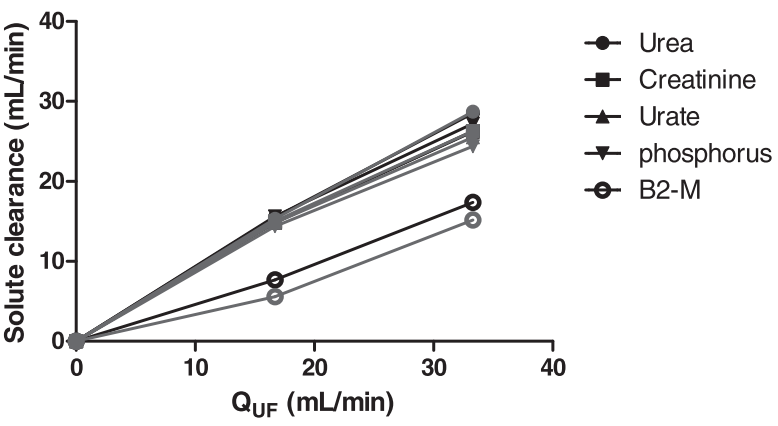

FIG. 2. Influence of $Q_{\mathrm{UF}}$ and molecular weight on mean solute clearance at a blood flow of $150 \mathrm{ml} /$ minute. Color indicates the type of filter, where black-colored has a surface area of $0.6 \mathrm{~m}^{2}$ and gray-colored has a surface area of $0.9 \mathrm{~m}^{2}$ (graphs redrawn from data in Brunet et al (13)., with permission from Elsevier).

$(45,75)$. In predilution $\mathrm{HF}$, the $Q_{\mathrm{UF}}$ can be theoretically as high as $400 \mathrm{ml} /$ minute during intermittent HF $(76,77)$. With CRRT, the total effluent can reach $8-101$ /hour with current machines.

Clearance is also proportional to $Q_{\mathrm{B}}(75)$, as higher $Q_{\mathrm{B}}$ reduces the extent to which the predilution replacement fluid dilutes the solute concentration. For example, at a $Q_{\mathrm{UF}}$ of $21 /$ hour, tripling $Q_{\mathrm{B}}$ from $150 \mathrm{ml} /$ minute to $450 \mathrm{ml} /$ minute increases urea clearances by approximately $15 \%$; at a $Q_{\mathrm{UF}}$ of $6 \mathrm{l} /$ hour, tripling $Q_{\mathrm{B}}$ rates from 150 to $450 \mathrm{ml} / \mathrm{min}$ ute increases urea clearances by approximately $35 \%$ $(45,75)$. Increases in $Q_{\mathrm{B}}$ have a more limited effect on the removal of larger molecules such as $\beta_{2}$-microglobulin compared with smaller molecules (45).

The usual $Q_{\mathrm{B}}$ in intermittent $\mathrm{HF}$ is $300 \mathrm{ml} / \mathrm{min}$ ute, compared with $150-250 \mathrm{ml} /$ minute in CRRT, although higher flows are possible depending on the vascular access.

Limitations. Although postdilution hemofiltration can be associated with enhanced clearance compared with a similar $Q_{\mathrm{UF}}$ administered predilution, it has been argued that for small, middle, and protein-bound molecules this advantage is of minor clinical significance $(13,65)$. However, in other studies, a $40 \%$ increase in clearance occurred as $Q_{\mathrm{UF}}$ increased $(45,66)$.

In postdilution $\mathrm{HF}$, the maximum $Q_{\mathrm{UF}}$ depends, in part, on $Q_{\mathrm{B}}$ and the relationship can be described by the filtration fraction, which is calculated as $Q_{\mathrm{UF}}$ divided by $Q_{\mathrm{B}}$. The filtration fraction should be less than $30 \%$ to avoid hemoconcentration and high filter transmembrane pressures (TMP), which impair filter performance $(74,77,78)$.

Postdilution HF is associated with an increased risk of clotting of the filter and requires anticoagulation, which is not essential in predilution (77).

\section{Use of a Large High-Flux Filter, Particularly for Middle-Sized Solutes}

Principles. The clearance of middle MW solutes depends, in part, on solvent drag due to ultrafiltration. 
Therefore, the preferred ECTR for middle molecules is hemofiltration using large high-flux membranes.

Supporting Data. Most existing high-flux membranes have a $B_{2}$-microglobulin clearance of at least $20 \mathrm{ml} /$ minute and a $K_{\mathrm{UF}}>20 \mathrm{ml} /$ hour $/ \mathrm{mmHg}$ (79); this $K_{\mathrm{UF}}$ value represents the current recommendation for filters used in intermittent haemodiafiltration (78).

When convection is performed in isolation, highefficiency and conventional dialysis filters have a minor effect compared with lower efficiency filters on the clearance of small $(<500-1000 \mathrm{Da})(45,66,80)$ and larger molecules $(1,13,40,41,45,56,81)$. However, clearances of middle-sized solutes up to 10,000 Da are clearly higher with a high-flux membrane and become negligible with a $\mathrm{MW}>20,000 \mathrm{Da}(63,82)$. Another advantage of a larger filter surface area (for example, $2.2 \mathrm{~m}^{2}$ compared to $1.4 \mathrm{~m}^{2}$ ) is that it can withstand greater transmembrane pressures for a longer period of time (13), allowing higher $Q_{\mathrm{B}}$ and convective fluxes across the membrane $(45,74)$.

Newer dialyzer membranes have been developed for certain clinical scenarios. Protein-leaking membranes, also named high cut-off (HCO) or "superflux" membranes, are highly permeable membranes with improved removal of protein-bound solutes and larger sized unbound solutes (63). For example, compared with high-flux filters, protein-leaking membranes increase $B_{2}$-microglobulin removal, although this is at the expense of a heavier albumin loss (83). These filters have a more complex effect than the simple leakage of albumin and its bound constituents across their membrane (63). Current applications include the removal of light chains in multiple myeloma (84). Very high capacity filters are also used during therapeutic plasma exchange using a filtration technique. Protein-leaking membranes have potential applications in toxicology for poisons that are highly protein-bound, especially considering that albumin loss likely has negligible clinical significance when these filters are used for a limited number of sessions (63).

Limitations. The material used for the filter membrane can influence clearance. For example, solute clearances with AN69 seem lower than with other membranes $(72,85-88)$. In convection, solutes may be adsorbed to the filter. The effect is more pronounced for middle and large MW molecules and is maximal within the first hours after a filter change (89-93). However, the impact of adsorption cannot be easily predicted by analyzing the filter and the MW of the poison (68). Therefore, it should not be assumed that all high-flux hemofilters provide comparable clearance simply based on their characteristics $(66,69,74)$. Filter efficacy also decreases with time, especially after 48 hours $(94,95)$. Recommendations from the manufacturers include filter change every $48-72$ hours to preserve the filter clearance capacity, regardless of the adsorptive process (91).
It is unclear whether protein-leaking membranes offer benefits beyond those obtained with conventional high-flux membranes, because data are limited (63).

\section{Use of Convection and Diffusion}

Diffusion and convection have a comparable effect on the clearance of smaller MW molecules $(<500-1000 \mathrm{Da})$, while convection provides much higher clearances for middle MW molecules (1000$10,000 \mathrm{Da})$ compared with diffusion. Therefore, clearance of small MW molecules can be enhanced by adding convection to diffusion, thereby increasing total effluent rate (96), although the opposite is not true for middle MW molecules. As previously mentioned, for each modality, the actual clearance achieved will depend on the $Q_{\mathrm{B}}, Q_{\mathrm{UF}}$, or $Q_{\mathrm{D}}$ used. Examples from the poisoning literature are limited, but lithium clearance in one report was similar with CVVH and CVVHD at similar effluent rates (96).

Although the two clearances are not additive, there seems to be only a minimal interaction between them in CVVHDF (13). However, in HDF, ultrafiltration and predilution may have a negative impact on transmembrane concentration gradients $(77,78)$. Nevertheless, the addition of convection may improve clearance of some solutes, like phosphorus (97). With newer machines, the maximal effluent flow in CRRT is 8-10 1/hour, while $Q_{\text {UF }}$ can reach 241 /hour in predilution HDF, assuming a $Q_{\text {B }}$ of $350-400 \mathrm{ml} /$ minute.

\section{Adsorption}

Adsorption is a process by which particles located in the blood compartment bind reversibly or irreversibly to the surface of a column (or sorbent). This process is central to hemoperfusion and is covered in detail in the dedicated article on hemoperfusion presented in this issue.

Although adsorption may occur during diffusive and especially convective techniques, its contribution to total clearance is variable, and cannot be easily predicted by considering the type of filter and/or the MW of the poison (68). Adsorption is usually considered to have a minor effect on clearance compared with convection and diffusion, is more pronounced for middle and large MW molecules, and largely occurs within the first hour after a filter change (89-93).

\section{Centrifugation}

Centrifugation and convection are the major processes implicated in plasmapheresis techniques. Centrifugation separates the whole blood into various components according to their specific gravity, and is usually used to remove pathogenic proteins such as antibodies. Centrifugation may also be useful to remove large or protein-bound solutes located in the plasma. 
Centrifugation can be performed intermittently or continuously (98). With intermittent centrifugation, blood is drawn in successive batches through flow separators to remove a target volume of plasma. With continuous-flow equipment, blood flows continuously into a rotating device in which red cells, leukocytes, platelets, and plasma separate into layers according to their respective specific gravity. Any of these layer(s) can be removed, and the remainder is returned to the patient along with a replacement fluid. Continuous-flow centrifugation is fully automated and is faster than intermittent centrifugation (98).

\section{Maximization of the Volume of Plasma Exchanged}

The major factor influencing clearance with centrifugation is the total volume of plasma exchanged per session (99). In therapeutic plasma exchange (TPE), a single exchange of one plasma volume (defined as a patient's entire plasma volume and corresponds to 31 for a $70 \mathrm{~kg}$ patient) removes $63 \%$ of all solutes in plasma. An exchange of 2 plasma volumes removes $86 \%$ of solutes, while a third would decrease initial solute concentration by $95 \%(100,101)$.

In the treatment of a poisoned patient, the American Society for Apheresis (ASFA) guidelines recommend an exchange volume of one to two total plasma volumes per day until clinical symptoms have decreased and the release of toxin from tissues is no longer significant (102). However, as acknowledged, this recommendation was based on limited data.

\section{Choice of Replacement Fluid}

The choice of the replacement volume may be guided by the affinity of the poison to its main binding protein. For example, the ASFA guidelines suggest that fresh frozen plasma may be the most appropriate choice in poisoning from drugs like quinidine, imipramine, and propranolol, as these drugs have a great affinity for alpha-1-acid glycoprotein (102). However, this is debatable because of their large $V_{\mathrm{D}}$, which limits total body removal, and the relatively small concentration of alpha-1-acid glycoprotein in plasma (21). Finally, in TPE with filtration, the surface area of the filter does not seem to significantly influence clearances, which is different than for dialysis or convection (99).

\section{Clearance Parameters Applicable to All Processes}

\section{Treatment Time}

Assuming that a poison is removable by ECTR and there is no filter saturation, the concentration of poison in the blood would decrease steadily and progressively, usually according to first-order kinet- ics. For some molecules, the treatment time is the most important factor determining poison removal (81), so the "routine" 4-hour treatment reserved for patients with end-stage renal disease (ESRD) should be challenged in the treatment of a poisoned patient. Classical examples include prolonged IHD for poisoning from lithium or aspirin (103).

\section{Location, Length, and Size of the Intravascular Catheter}

The maximum achievable $\mathrm{Q}_{\mathrm{B}}$ depends on the location of the intravascular catheter, its lumen size, and length. A recent large randomized trial from the Cathedia study group showed that catheters placed in the right jugular or the femoral vein are associated with less dysfunction than those placed in the left jugular vein (104); the subclavian site is not favored in patients at risk for ESRD (105), although its recirculation rate is similar to that in the jugular vein (106). If a femoral catheter is used, its length should be longer than $20 \mathrm{~cm}$, ideally $25 \mathrm{~cm}$, to minimize recirculation (104,106-108).

These considerations should be weighed against the experience of the operator, complication rate, and the time required to install the catheter, as well as the delay to perform a X-ray confirming the position of the subclavian or jugular catheter. While these data are derived from diffusion-based techniques, they are likely valid for convection as well. For TPE by centrifugation and filtration, a central catheter also allows optimizing blood flow rate and clearance $(109,110)$. However, as the $Q_{\mathrm{B}}$ is much lower in TPE than with other techniques, the catheter location, size, and length are not as important as with other techniques. As an example, the $Q_{\mathrm{B}}$ is usually $100 \mathrm{ml} /$ minute for TPE with centrifugation $(104,105)$ and $100-200 \mathrm{ml} /$ minute for TPE with filtration (99).

\section{Administration of Anticoagulation According to Usual Procedure}

Anticoagulation is usually required for ECTR to ensure continuing efficacy of the procedure. Clotting reduces filter/column performance and may reduce the overall effect of ECTR if the circuit needs to be changed. During diffusion-based procedures, heparin-free chronic IHD does not appear to significantly reduce solute clearance if there is no clotting of the circuit (111). Studies in acute settings are required to validate this observation.

Clinical experience suggests that predilution intermittent HDF can be performed without anticoagulation, while postdilution intermittent HDF usually requires anticoagulation because of increased viscosity of blood in the hemofilter. In CRRT, filter life is independent of heparin dose (including $700 \mathrm{U} /$ hour) (112). However, filter life is significantly shorter when postdilution is used instead of predilution $(113,114)$. Anticoagulation is required for TPE, whereby citrate is most frequently used during cen- 
trifugation, while heparin is used for filtration (98). The influence of anticoagulation on the elimination of poison needs to be further studied in TPE.

\section{Conclusion}

The use of an ECTR for enhanced elimination in poisoned patients can be effective for a limited number of poisons. Optimizing extracorporeal clearance can benefit patients by reducing toxicity, but it may also reduce the utilization of health resources by shortening the duration of treatment and overall hospital length of stay.

In this manuscript, we aimed to review the various components of ECTR and highlight the modalities and parameters that are most likely to enhance clearance. However, data supporting some of these recommendations are limited, particularly in the context of poisoning. Therefore, clinical decisions should be made on a case-by-case basis by specifically considering the actual poison, clinical circumstances, patient characteristics, and available techniques.

\section{References}

1. Mandolfo S, Malberti F, Imbasciati E, Cogliati P, Gauly A: Impact of blood and dialysate flow and surface on performance of new polysulfone hemodialysis dialyzers. Int J Artif Organs 26:113-120, 2003

2. Allen R, Frost TH, Hoenich NA: The influence of the dialysate flow rate on hollow fiber hemodialyzer performance. Artif Organs 19:1176-1180, 1995

3. Leypoldt JK, Cheung AK, Agodoa LY, Daugirdas JT, Greene T, Keshaviah PR: Hemodialyzer mass transfer-area coefficients for urea increase at high dialysate flow rates. The Hemodialysis (HEMO) Study. Kidney Int 51:2013-2017, 1997

4. Ouseph R, Ward RA: Increasing dialysate flow rate increases dialyzer urea mass transfer-area coefficients during clinical use. $\mathrm{Am} \mathrm{J}$ Kidney Dis 37:316-320, 2001

5. Borzou SR, Gholyaf M, Zandiha M, Amini R, Goodarzi MT, Torkaman B: The effect of increasing blood flow rate on dialysis adequacy in hemodialysis patients. Saudi J Kidney Dis Transpl 20:639-642, 2009

6. Munshi R, Ahmad S: Comparison of urea clearance in low-efficiency low-flux vs. high-efficiency high-flux dialyzer membrane with reduced blood dialysate flow An in vitro analysis. Hemodial Int $18: 172-174,2014$

7. Gutzwiller JP, Schneditz D, Huber AR, Schindler C, Garbani E, Zehnder CE: Increasing blood flow increases kt/V(urea) and potassium removal but fails to improve phosphate removal. Clin Nephrol 59:130-136, 2003

8. Ward RA: Blood flow rate: an important determinant of urea clearance and delivered Kt/V. Adv Ren Replace Ther 6:75-79, 1999

9. Hauk M, Kuhlmann MK, Riegel W, Kohler H: In vivo effects of dialysate flow rate on $\mathrm{Kt} / \mathrm{V}$ in maintenance hemodialysis patients. Am J Kidney Dis 35:105-111, 2000

10. Bhimani JP, Ouseph R, Ward RA: Effect of increasing dialysate flow rate on diffusive mass transfer of urea, phosphate and beta2microglobulin during clinical haemodialysis. Nephrol Dial Transplant 25: 3990-3995, 2010

11. Davenport A, Will EJ, Davison AM: Effect of the direction of dialysate flow on the efficiency of continuous arteriovenous haemodialysis. Blood Purif 8:329-336, 1990

12. Relton S, Greenberg A, Palevsky PM: Dialysate and blood flow dependence of diffusive solute clearance during CVVHD. ASAIO J 38:M691-M696, 1992

13. Brunet S, Leblanc M, Geadah D, Parent D, Courteau S, Cardinal $\mathrm{J}$ : Diffusive and convective solute clearances during continuous renal replacement therapy at various dialysate and ultrafiltration flow rates. Am J Kidney Dis 34:486-492, 1999
14. Gong D, Ji D, Xie H, Xu B, Liu Y, Li L: The effects of dialysate and ultrafiltration flow rate on solute clearance during continuous renal replacement therapy. Zhonghua Nei Ke Za Zhi 40:183-186, 2001

15. Churchwell MD, Pasko DA, Smoyer WE, Mueller BA: Enhanced clearance of highly protein-bound drugs by albumin-supplemented dialysate during modeled continuous hemodialysis. Nephrol Dial Transplant 24:231-238, 2009

16. Bonnardeaux A, Pichette V, Ouimet D, Geadah D, Habel F, Cardinal J: Solute clearances with high dialysate flow rates and glucose absorption from the dialysate in continuous arteriovenous hemodialysis. Am J Kidney Dis 19:31-38, 1992

17. Wilson FP, Bachhuber MA, Caroff D, Adler R, Fish D, Berns J: Low cefepime concentrations during high blood and dialysate flow continuous venovenous hemodialysis. Antimicrob Agents Chemother $56: 2178-2180,2012$

18. Meyer TW, Leeper EC, Bartlett DW, Depner TA, Lit YZ, Robertson CR, Hostetter TH: Increasing dialysate flow and dialyzer mass transfer area coefficient to increase the clearance of protein-bound solutes. J Am Soc Nephrol 15:1927-1935, 2004

19. Luo FJ, Patel KP, Marquez IO, Plummer NS, Hostetter TH, Meyer TW: Effect of increasing dialyzer mass transfer area coefficient and dialysate flow on clearance of protein-bound solutes: a pilot crossover trial. Am J Kidney Dis 53:1042-1049, 2009

20. Sirich TL, Luo FJ, Plummer NS, Hostetter TH, Meyer TW: Selectively increasing the clearance of protein-bound uremic solutes. Nephrol Dial Transplant 27:1574-1579, 2012

21. Roberts DM, Buckley NA: Pharmacokinetic considerations in clinical toxicology: clinical applications. Clin Pharmacokinet 46:897-939, 2007

22. Franssen EJ, van Essen GG, Portman AT, de Jong J, Go G, Stegeman CA, Uges DR: Valproic acid toxicokinetics: serial hemodialysis and hemoperfusion. Ther Drug Monit 21:289-292, 1999

23. Lanese DM, Alfrey PS, Molitoris BA: Markedly increased clearance of vancomycin during hemodialysis using polysulfone dialyzers. Kidney Int 35:1409-1412, 1989

24. Bosl R, Shideman JR, Meyer RM, Buselmeier TJ, von Hartitzsch B, Kjellstrand CM: Effects and complications of high efficiency dialysis. Nephron 15:151-160, 1975

25. Voiculescu A, Hefter H, Falck M, Kutkuhn B, Grabensee B: Hemodialysis in severe lithium intoxication [German]. Intensivmed Notfallmed 32:433-437, 1995

26. Lee CS, Peterson JC, Marbury TC: Comparative pharmacokinetics of theophylline in peritoneal dialysis and hemodialysis. J Clin Pharmacol 23:274-280, 1983

27. Pond SM: Extracorporeal techniques in the treatment of poisoned patients. Med J Aust 154:617-622, 1991

28. Holubek WJ, Hoffman RS, Goldfarb DS, Nelson LS: Use of hemodialysis and hemoperfusion in poisoned patients. Kidney Int 74:1327-1334, 2008

29. Fertel BS, Nelson LS, Goldfarb DS: Extracorporeal removal techniques for the poisoned patient: a review for the intensivist. $J$ Intensive Care Med 25:139-148, 2010

30. Manley HJ, Bridwell DL, Elwell RJ, Bailie GR: Influence of peritoneal dialysate flow rate on the pharmacokinetics of cefazolin. Perit Dial Int 23:469-474, 2003

31. Ullian ME, Parker H, Sibbald LD, Peabody AM, Schattner P, Jensen JF: Effect of increasing dialysate flow rates on adequacy of peritoneal dialysis. Perit Dial Int 20:571-574, 2000

32. Rubin J, Adair C, Barnes T, Bower J: Dialysate flow rate and peritoneal clearance. Am J Kidney Dis 4:260-267, 1984

33. Robson M, Oreopoulos DG, Izatt S, Ogilvie R, Rapoport A, deVeber GA: Influence of exchange volume and dialysate flow rate on solute clearance in peritoneal dialysis. Kidney Int 14:486-490, 1978

34. Freida P, Issad B: Continuous flow peritoneal dialysis: assessment of fluid and solute removal in a high-flow model of "fresh dialysate single pass". Perit Dial Int 23:348-355, 2003

35. Ronco C, Dell'Aquila R, Bonello M, Gloukhoff A, Amerling R, Cruz C, Levin N: Continuous flow peritoneal dialysis: a new double lumen catheter. Int J Artif Organs 26:984-990, 2003

36. Szepietowski T, Weyde W, Stefanska-Bac E: Methanol elimination in peritoneal dialysis [Polish]. Pol Tyg Lek 30 (22):933-935, 1975

37. Kan G, Jenkins I, Rangan G, Woodroffe A, Rhodes H, Joyce D: Continuous haemodiafiltration compared with intermittent haemodialysis in the treatment of methanol poisoning. Nephrol Dial Transplant 18:2665-2667, 2003

38. Brandes JC, Packard WJ, Watters SK, Fritsche C: Optimization of dialysate flow and mass transfer during automated peritoneal dialysis. Am J Kidney Dis 25:603-610, 1995

39. Aasarod K, Wideroe TE, Flakne SC: A comparison of solute clearance and ultrafiltration volume in peritoneal dialysis with total or fractional $(50 \%)$ intraperitoneal volume exchange with the same dialysate flow rate. Nephrol Dial Transplant 12:2128-2132, 1997 
40. Eloot S, de Vos JY, de Vos F, Hombrouckx R, Verdonck P: Middle molecule removal in low-flux polysulfone dialyzers: impact of flows and surface area on whole-body and dialyzer clearances. Hemodial Int 9:399-408, 2005

41. Leypoldt JK, Cheung AK: Removal of high-molecular-weight solutes during high-efficiency and high-flux haemodialysis. Nephrol Dial Transplant 11:329-335, 1996

42. Trerotola SO, Shah H, Johnson M, Namyslowski J, Moresco K, Patel N, Kraus M, Gassensmith C, Ambrosius WT: Randomized comparison of high-flow versus conventional hemodialysis catheters J Vasc Interv Radiol 10:1032-1038, 1999

43. Szabo J, Locking-Cusolito $\mathrm{H}$ : The impact of increased blood flow rates on recirculation in central venous hemodialysis catheters. Nephrol Nurs $J$ 28:639-641, 2001

44. Pannu N, Jhangri GS, Tonelli M: Optimizing dialysis delivery in tunneled dialysis catheters. ASAIO J 52:157-162, 2006

45. Wizemann V, Kulz M, Techert F, Nederlof B: Efficacy of haemodiafiltration. Nephrol Dial Transplant 16(Suppl 4):27-30, 2001

46. Azar AT: Increasing dialysate flow rate increases dialyzer urea clearance and dialysis efficiency: an in vivo study. Saudi J Kidney Dis Transpl 20:1023-1029, 2009

47. Wolter K, Claus M, Wagner K, Fritschka E: Teicoplanin pharmacokinetics and dosage recommendations in chronic hemodialysis patients and in patients undergoing continuous veno-venous hemodialysis. Clin Nephrol 42:389-397, 1994

48. Eknoyan G, Beck GJ, Cheung AK, Daugirdas JT, Greene T, Kusek JW, Allon M, Bailey J, Delmez JA, Depner TA, Dwyer JT, Levey AS, Levin NW, Milford E, Ornt DB, Rocco MV, Schulman G, Schwab SJ, Teehan BP, Toto R; Hemodialysis Study G: Effect of dialysis dose and membrane flux in maintenance hemodialysis. $N$ Engl J Med 347: 2010-2019, 2002

49. Matzke GR: Status of hemodialysis of drugs in 2002. J Pharm Pract 15:405-418, 2002

50. Schuerer DJ, Brophy PD, Maxvold NJ, Kudelka T, Bunchman TE: High-efficiency dialysis for carbamazepine overdose. J Toxicol Clin Toxicol 38:321-323, 2000

51. Lesaffer G, De Smet R, Lameire N, Dhondt A, Duym P, Vanholder $\mathrm{R}$ : Intradialytic removal of protein-bound uraemic toxins: role of solute characteristics and of dialyser membrane. Nephrol Dial Transplant 15:50-57, 2000

52. Powers KM, Wilkowski MJ, Helmandollar AW, Koenig KG, Bolton WK: Improved urea reduction ratio and $\mathrm{Kt} / \mathrm{V}$ in large hemodialysis patients using two dialyzers in parallel. Am J Kidney Dis $35: 266-274,2000$

53. Fritz BA, Doss S, McCann LM, Wrone EM: A comparison of dual dialyzers in parallel and series to improve urea clearance in large hemodialysis patients. Am J Kidney Dis 41:1008-1015, 2003

54. Panzer U, Kluge S, Kreymann G, Wolf G: Combination of intermittent haemodialysis and high-volume continuous haemofiltration for the treatment of severe metformin-induced lactic acidosis. Nephrol Dial Transplant 19:2157-2158, 2004

55. Friesecke S, Abel P, Kraft M, Gerner A, Runge S: Combined renal replacement therapy for severe metformin-induced lactic acidosis. Nephrol Dial Transplant 21:2038-2039, 2006

56. Ouseph R, Hutchison CA, Ward RA: Differences in solute removal by two high-flux membranes of nominally similar synthetic polymers. Nephrol Dial Transplant 23:1704-1712, 2008

57. Maduell F, Navarro V, Cruz MC, Torregrosa E, Garcia D, Simon $V$, Ferrero JA: Osteocalcin and myoglobin removal in on-line hemodiafiltration versus low- and high-flux hemodialysis. Am J Kidney Dis 40:582-589, 2002

58. Sen S, Ratnaraj N, Davies NA, Mookerjee RP, Cooper CE, Patsalos PN, Williams R, Jalan R: Treatment of phenytoin toxicity by the molecular adsorbents recirculating system (MARS). Epilepsia 44:265-267, 2003

59. Askenazi DJ, Goldstein SL, Chang IF, Elenberg E, Feig DI: Management of a severe carbamazepine overdose using albuminenhanced continuous venovenous hemodialysis. Pediatrics 113:406409, 2004

60. Peszynski P, Klammt S, Peters E, Mitzner S, Stange J, Schmidt R Albumin dialysis: single pass vs. recirculation (MARS). Liver 22 (Suppl 2):40-42, 2002

61. Drexler K, Baustian C, Richter G, Ludwig J, Ramlow W, Mitzner $\mathrm{S}$ : Albumin dialysis molecular adsorbents recirculating system: impact of dialysate albumin concentration on detoxification efficacy. Ther Apher Dial 13:393-398, 2009

62. Krisper P, Stadlbauer V, Stauber RE: Clearing of toxic substances: are there differences between the available liver support devices? Liver Int 31(Suppl 3):5-8, 2011

63. Ward RA: Protein-leaking membranes for hemodialysis: a new class of membranes in search of an application? J Am Soc Nephrol $16: 2421-2430,2005$

64. Ward RA, Schmidt B, Hullin J, Hillebrand GF, Samtleben W: A comparison of on-line hemodiafiltration and high-flux hemodialy- sis: a prospective clinical study. J Am Soc Nephrol 11:2344-2350, 2000

65. Bammens B, Evenepoel P, Verbeke K, Vanrenterghem Y: Remova of the protein-bound solute p-cresol by convective transport: a randomized crossover study. Am J Kidney Dis 44:278-285, 2004

66. Troyanov S, Cardinal J, Geadah D, Parent D, Courteau S, Caron S, Leblanc M: Solute clearances during continuous venovenous haemofiltration at various ultrafiltration flow rates using Multiflow-100 and HF1000 filters. Nephrol Dial Transplant 18:961-966, 2003

67. Gong X: Evaluation of Hemperfusion in early treatment of acute organophosphoris pesticide poisoning. Acta Acad Med Nantong 24 (2):201-202, 2004

68. Yamashita AC: Mechanisms of solute and fluid removal in hemodiafiltration. Contrib Nephrol 158:50-56, 2007

69. Ahrenholz PG, Winkler RE, Michelsen A, Lang DA, Bowry SK: Dialysis membrane-dependent removal of middle molecules during hemodiafiltration: the beta2-microglobulin/albumin relationship. Clin Nephrol 62:21-28, 2004

70. Maduell F, del Pozo C, Garcia H, Sanchez L, Hdez-Jaras J, Albero MD, Calvo C, Torregrosa I, Navarro V: Change from conventional haemodiafiltration to on-line haemodiafiltration. Nephrol Dial Transplant 14:1202-1207, 1999

71. Panich A, Tiranathanagul K, Praditpornsilpa K, Eiam-Ong S: The effectiveness of on-line hemodiafiltration on beta-2 microglobulin clearance in end stage renal disease. J Med Assoc Thai 89(Suppl 2): S1-S8, 2006

72. Churchwell MD, Pasko DA, Mueller BA: Daptomycin clearance during modeled continuous renal replacement therapy. Blood Purif 24:548-554, 2006

73. Lau AH, Kronfol NO: Effect of continuous hemofiltration on phenytoin elimination. Ther Drug Monit 16:53-57, 1994

74. Penne EL, van der Weerd NC, Bots ML, van den Dorpel MA, Grooteman MP, Levesque R, Nube MJ, Ter Wee PM, Blankestijn $\mathrm{PJ}$; investigators $\mathrm{C}$ : Patient- and treatment-related determinants of convective volume in post-dilution haemodiafiltration in clinical practice. Nephrol Dial Transplant 24: 3493-3499, 2009

75. Gashti CN, Rodby RA, Huang Z, Gao D, Zhang W: Effects of high blood flow and high pre-dilution replacement fluid rates on small solute clearances in hemofiltration. Blood Purif 32:266-270, 2011

76. Altieri P, Sorba G, Bolasco P, Asproni E, Ledebo I, Cossu M, Ferrara R, Ganadu M, Cadinu F, Serra G, Cabiddu G, Sau G, Casu D, Passaghe M, Bolasco F, Pistis R, Ghisu T; Second Sardinian Multicentre S: Predilution haemofiltration-the Second Sardinian Multicentre Study: comparisons between haemofiltration and haemodialysis during identical $\mathrm{Kt} / \mathrm{V}$ and session times in a longterm cross-over study. Nephrol Dial Transplant 16:1207-1213, 2001

77. Colussi G, Frattini G: Quantitative analysis of convective dose in hemofiltration and hemodiafiltration: "predilution" vs. "postdilution" reinfusion. Hemodial Int 11:76-85, 2007

78. Tattersall JE, Ward RA; Group E: Online haemodiafiltration: definition, dose quantification and safety revisited. Nephrol Dial Transplant 28:542-550, 2013

79. Clark WR, Ronco C: Determinants of haemodialyser performance and the potential effect on clinical outcome. Nephrol Dial Transplant 16(Suppl 5):56-60, 2001

80. Jeffrey RF, Khan AA, Prabhu P, Todd N, Goutcher E, Will EJ, Davison AM: A comparison of molecular clearance rates during continuous hemofiltration and hemodialysis with a novel volumetric continuous renal replacement system. Artif Organs 18:425-428, 1994

81. Ratanarat R, Brendolan A, Volker G, Bonello M, Salvatori G, Andrikos E, Yavuz A, Crepaldi C, Ronco C: Phosphate kinetics during different dialysis modalities. Blood Purif 23:83-90, 2005

82. Cheung AK, Leypoldt JK: The hemodialysis membranes: a historical perspective, current state and future prospect. Semin Nephrol 17:196-213, 1997

83. Pellicano R, Polkinghorne KR, Kerr PG: Reduction in beta2-microglobulin with super-flux versus high-flux dialysis membranes: results of a 6-week, randomized, double-blind, crossover trial. Am J Kidney Dis 52:93-101, 2008

84. Martin-Reyes G, Toledo-Rojas R, Torres-de Rueda A, Sola-Moyano E, Blanca-Martos L, Fuentes-Sanchez L, Martinez-Esteban MD, Diez-de los Rios MJ, Bailen-Garcia A, Gonzalez-Molina M, Garcia-Gonzalez I: Haemodialysis using high cut-off dialysers for treating acute renal failure in multiple myeloma. Nefrologia 32:3543, 2012

85. Matzke GR, Frye RF, Joy MS, Palevsky PM: Determinants of ceftriaxone clearance by continuous venovenous hemofiltration and hemodialysis. Pharmacotherapy 20:635-643, 2000

86. Joy MS, Matzke GR, Frye RF, Palevsky PM: Determinants of vancomycin clearance by continuous venovenous hemofiltration and continuous venovenous hemodialysis. Am J Kidney Dis 31:1019 1027, 1998

87. Stevenson JM, Patel JH, Churchwell MD, Vilay AM, Depestel DD, Sorgel F, Kinzig M, Jakob V, Mueller BA: Ertapenem clearance 


\section{Bouchard et al.}

during modeled continuous renal replacement therapy. Int $J$ Artif Organs 31:1027-1034, 2008

88. Patel JH, Churchwell MD, Seroogy JD, Barriere SL, Grio M, Mueller B: Telavancin and hydroxy propyl-beta-cyclodextrin clearance during continuous renal replacement therapy: an in vitro study. Int $J$ Artif Organs 32:745-751, 2009

89. Choi G, Gomersall CD, Lipman J, Wong A, Joynt GM, Leung P, Ramsay SJ, Ho OM: The effect of adsorption, filter material and point of dilution on antibiotic elimination by haemofiltration an in vitro study of levofloxacin. Int J Antimicrob Agents 24:468-472, 2004

90. Davies JG, Kingswood JC, Sharpstone P, Street MK: Drug removal in continuous haemofiltration and haemodialysis. $\mathrm{Br} J$ Hosp Med 54:524-528, 1995

91. De Vriese AS, Colardyn FA, Philippe JJ, Vanholder RC, De Sutter JH, Lameire NH: Cytokine removal during continuous hemofiltration in septic patients. J Am Soc Nephrol 10:846-853, 1999

92. Kronfol NO, Lau AH, Colon-Rivera J, Libertin CL: Effect of $\mathrm{CAVH}$ membrane types on drug-sieving coefficients and clearances. ASAIO Trans 32:85-87, 1986

93. Birk HW, Kistner A, Wizemann V, Schutterle G: Protein adsorption by artificial membrane materials under filtration conditions. Artif Organs 19:411-415, 1995

94. Boyle M, Wyndham K, Jacobs S, Torda TA: Comparative clearance performance of two dialyser units used in the CVVHD mode. Aust Crit Care 8:20-25, 1995

95. Pasko DA, Churchwell MD, Salama NN, Mueller BA: Longitudinal hemodiafilter performance in modeled continuous renal replacement therapy. Blood Purif 32:82-88, 2011

96. Hazouard E, Ferrandiere M, Rateau H, Doucet O, Perrotin D, Legras A: Continuous veno-venous haemofiltration versus continuous veno-venous haemodialysis in severe lithium self-poisoning: a toxicokinetics study in an intensive care unit. Nephrol Dial Transplant 14:1605-1606, 1999

97. Lornoy W, De Meester J, Becaus I, Billiouw JM, Van Malderen PA, Van Pottelberge M: Impact of convective flow on phosphorus removal in maintenance hemodialysis patients. J Ren Nutr 16:47-53, 2006

98. Madore F: Plasmapheresis technical aspects and indications. Crit Care Clin 18(2):375-392, 2002

99. Tan HK, Hart G: Plasma filtration. Ann Acad Med Singapore $34: 615-624,2005$

100. Jones JS, Dougherty J: Current status of plasmapheresis in toxicology. Ann Emerg Med 15:474-482, 1986

101. Shelat SG: Practical considerations for planning a therapeutic apheresis procedure. Am J Med 123:777-784, 2010

102. Szczepiorkowski ZM, Winters JL, Bandarenko N, Kim HC, Linenberger ML, Marques MB, Sarode R, Schwartz J, Weinstein R, Shaz
BH; Apheresis Applications Committee of the American Society for A: Guidelines on the use of therapeutic apheresis in clinical practice-evidence-based approach from the Apheresis Applications Committee of the American Society for Apheresis. J Clin Apher 25:83-177, 2010

103. Treysman L, Meehan TJ, Schlieben DJ, Ducre B, Erickson TB: Pharmacokinetic Modeling of Lithium Elimination During 67 Continuous Hours of High Flux Hemodialysis (abstract). Clin Toxicol 48:647, 2010

104. Parienti JJ, Megarbane B, Fischer MO, Lautrette A, Gazui N, Marin N, Hanouz JL, Ramakers M, Daubin C, Mira JP, Charbonneau P, du Cheyron D; Cathedia Study G: Catheter dysfunction and dialysis performance according to vascular access among 736 critically ill adults requiring renal replacement therapy: a randomized controlled study. Crit Care Med 38:1118-1125, 2010

105. Kidney Disease: Improving Global Outcomes (KDIGO) Acute Kidney Injury Work Group: KDIGO Clinical Practice Guideline for Acute Kidney Injury. Kidney Int Suppl 2: 1-138, 2012

106. Kelber J, Delmez JA, Windus DW: Factors affecting delivery of high-efficiency dialysis using temporary vascular access. Am J Kidney Dis 22:24-29, 1993

107. Leblanc M, Fedak S, Mokris G, Paganini EP: Blood recirculation in temporary central catheters for acute hemodialysis. Clin Nephrol 45:315-319, 1996

108. Little MA, Conlon PJ, Walshe JJ: Access recirculation in temporary hemodialysis catheters as measured by the saline dilution technique. Am J Kidney Dis 36:1135-1139, 2000

109. Okafor C, Kalantarinia K: Vascular access considerations for therapeutic apheresis procedures. Semin Dial 25:140-144, 2012

110. Schonermarck U, Bosch T: Vascular access for apheresis in intensive care patients. Ther Apher Dial 7:215-220, 2003

111. McGill RL, Blas A, Bialkin S, Sandroni SE, Marcus RJ: Clinical consequences of heparin-free hemodialysis. Hemodial Int 9:393-398, 2005

12. Martin PY, Chevrolet JC, Suter P, Favre H: Anticoagulation in patients treated by continuous venovenous hemofiltration: a retrospective study. Am J Kidney Dis 24:806-812, 1994

113. Uchino S, Fealy N, Baldwin I, Morimatsu H, Bellomo R: Pre-dilution vs. post-dilution during continuous veno-venous hemofiltration: impact on filter life and azotemic control. Nephron Clin Pract 94: c94-c98, 2003

114. van der Voort PH, Gerritsen RT, Kuiper MA, Egbers PH, Kingma WP, Boerma EC: Filter run time in CVVH: pre- versus post-dilution and nadroparin versus regional heparin-protamine anticoagulation. Blood Purif 23:175-180, 2005 